to our knowledge of glazes, colours, decorations, saggars, and in fact practically every department of pottery manufacture. It must be admitted that the times and conditions to which he was born conspired together to favour a rapid development of the pottery industry, and that other men of his day, Spode and Turner, for example, also made worthy contributions to that development. Nevertheless, it is clear that he was their acknowledged leader and a man of the greatest generosity and natural ability.

He died in January 1795 after a life dogged by ill-health, but inspired to the last with the creative enthusiasm of his craft.

\title{
The Importance of Cataclasms in Evolution.*
}

By Dr. G. P. BIDDer.

A

CATACLASM is the result of an exceptional drought, flood, heat, cold, volcanic disturbance, or change in constituents of atmosphere or ocean, or other change in environment which over a large area is fatal to all species or individuals saving those which are exceptionally provided, quantitatively or qualitatively, so as to survive the ordeal. This definition is in strict agreement with Southey's use of the word in 1834 (Oxford Dict.). We may consider the essential phenomenon of a cataclasm as the reduction, by some violent happening, of a populous region of earth or sea to sterile emptiness, which is repopulated by the few survivors of the disaster. $\dagger$ Destruction may come upon all living beings from a volcano, or from a volcanic wave upon land and freshwater organisms, or from a pandemic disease upon only a single group of animals.

Darwin recognised the importance of the cataclasm, but he rarely emphasised it, probably because diluvial doctrines had so long held the field. It is now generally overlooked in theoretical discussions. The possibility of a given speciescharacter or individual variation having survival value is commonly discussed from the point of view only of normal environment, without recognising that eschatological environment has equal or greater importance in the selection of races, and in regard to many characters must have been the only decisive factor.

If a small heritable quantitative or qualitative difference can lead to the survival of an individual in a catholic danger which destroys all individuals of the species not endowed with such a difference, then, though the danger recurs but once in 50,000 years, that difference must eventually be stereotyped as a character of the species. In the intervening 50,000 years of peace many successful variations may take place which do not include this saving difference, but they are pruned by the next similar cataclasm, the survivors of which will again all conform to type. Thus cataclasmic selection may enforce specific characters which are normally useless.

The position may be illustrated by considering at length the brief argument on the giraffe's neck

* Slightly modified from a paper read before the Linnean Society abstract in Proc. Linn. Soc. for Feb. 6, 1930.

† The word 'cataclysm' has a valuable use in its original technical significance of a widespread submergence of land. This was a legitimate application of the English form of the Greek word in Matthew xxiv, 38, the Vulgate Latin 'diluvium' having been reserved for the supposed post-Tertiary universal deluge. The modern protean use of "cataclysm" threatens to render the word unserviceable. in the sixth edition of the "Origin of Species", recalled to notice by Pycraft's interesting essay in Science Progress for January last. Darwin says: "The individuals which were the highest browsers and were able during dearths to reach even an inch or two above the others, will often have been preserved". The value of the passage is that it explains how, in the face of universal death, a very small quantitative advantage may save the individual. In normal times a giraffe with a neck two inches longer might gather 1 per cent more leaves than his brother and be perhaps $\frac{1}{2}$ per cent better nourished; and the advocatus diaboli is in his rights when he claims that this would have no survival value. In the great dearth, when all on the ground is eaten and the trees are stripped up to the full height that the tallest giraffes can reach, all must die of starvation. Yet if half a dozen giraffes now come who can reach two inches higher, they will find two inches of untouched leaves on every tree, and they alone may survive, to transmit their slightly longer necks to their progeny after the cataclasm. $\ddagger$

On these premises, there is little positive advantage to the progeny in having a long neck; the advantage in a dearth is in having a longer neck than the rest of the population. At the next similar cataclasm the survivors would be those with necks two inches longer than the now increased usual maximum of neck, and the survivors of the second cataclasm would transmit necks two increments longer than those of the original population. In a dearth, two inches added to the mean or modal length of neck might add, perhaps, a few hours to the duration of dearth required to kill off the herd; but the deviational excess of the length of neck in a single individual may ensure his solitary survival through another month of dearth. If this deviational excess be heritable, we have it enforced on the post-cataclasmal population as an example of what we may term 'futile' evolution; defining

* Such transmission will obviously take place to all descendants if the two-inch longer neck be a Mendelian recessive mutation, and to $8 / 9$ of the descendants if it be a Mendelian dominant, and the survivors show a typical sample of $2 D D+4 D R$. Most biologists would agree that there is no transmission if the extra height is merely 'metampic'-due to especially favourable accidents of nutrition and the like. But on Galton's " famous law of Heredity, which declared that to the total heritage of the offspring the parents on the average contribute $1 / 2$, the grandparents 1/4", etc., if we agree with Bateson (1909, "Mendel's Principles of Heredity", p. 6) that " there was admittedly a statistical accord between Galton's theory and some facts of heredity " and consider that the facts as to stature in giraffes probably come into this category,-then, if all the pre-cataclasmal ancestry be assumed normal, all the post-cataclasmal progeny would have a mean which deviates from the pre-cataclasmal mean by half the deviation of the survivors through the ordeal.

No. 3160, VoL. 125] 
'utile' evolution as that which enables the species to populate an environment where it could not otherwise have lived. (Futility in evolution, not cataclasmal, is shown by the useless height of the ' canopy' in forests the trees of which have long been forest-trees, competing each against his neighbour." In human affairs, competition between nations has produced alike the evolution of manufacturing machinery, which is utile, and the evolution of battleships, which is futile.)

Of the survivors who had been exposed to the Black Death in London many would have been selected for a physiological difference which enabled them to resist a single disease. Since many centuries of normal environment had not selected this difference, those who possessed it were probably inferior men in normal environment. The death in a war of a disproportionate number of the best of the nation is too widely and bitterly believed to be discussed.

The Black Death killed up to half the population, but we are considering especially cataclasms after which not 1 in 1000 is left alive. The problem presented itself in connexion with littoral sponges. I have maintained the thesis ${ }^{2}$ that the evolution of the canal-system in sponges can be shown to result in the continuously improved separation of the expelled water, which is foul and deprived of food, from the supply of fresh water taken in : the accepted sequence of evolution of the canal-system demonstrably, resulting in a more forcible jet from the vent, carrying the used water farther away from the sponge.

On the rocks of Plymouth Harbour grow in profusion the sponges Halichondria, Grantia, and Sycon. Sycon's well-known bottle-brush scheme of canals is most easily shown to result in the jet (represented by the handle of the bottle-brush) having enormously more power than its tributary currents, which pour into it radially along the bristles. Halichondria is the sponge in which Grant discovered sponge-currents: he vividly described the extraordinary power of the ejection of water from the volcano-like vents of the sponge. With Grantia I have been able to demonstrate to friends a jet some inches long, several times its own length, even from a rather unhappy sponge.

These three sponges live between tide-marks in the surf and the swirl, and the power of their jets is in that environment of absolutely no value to them. It is known that they have lived on similar rocks in those parts for a hundred years with a generation every year, and it is reasonably certain that they have so lived for 10,000 years, and probably very much longer. It seems certain, on the other hand, that their beautifully perfect canalsystem-so admirable adapted to bring them food and oxygen in still water-must be essential to them.

These apparent contradictions are reconciled if we consider that every now and again-maybe once, maybe a few times in a century - the whole of that littoral between tide-marks may have every sponge on it killed, and perhaps nearly every living thing. The most obvious means of death would seem to be if heavy rain, of the rare intensity of an inch in an hour, were to fall on the rocks during the two hours of lowest spring-tide. This would certainly not happen nearly once a century, but extreme heat from the sun at low spring-tide is another possible lethal agency, and in that part of the coast low springs are at the time of day when heat is greatest. Confining ourselves still to natural causes, a landslip might conceivably poison the water, or mud might, for a tide, cover a long stretch of shore.

After such a denudation the sponge population would be replaced by the larvæ from sponges in sheltered submarine caves. Of the enormous number of larva from the surf-sponges, a few will fix on every surface within a long range. The young sponge in a still, shut-in, cave will not grow so large or so fast as her sister among the waves, but she can live and grow because of her perfect current system, and her larva can swim to the light, out of the cave, and repopulate the shore. So that for the next century or so, until the next disaster, the rocks will grow thick again with Sycon, Grantia, and Halichondria, which will be all descended from a few ill-nourished individuals that at the time of the cataclasm lived in retreats where a powerful canal-system was necessary to life. Consequently we find the shore populated by littoral sponges with an elaborate anatomy which is useless for littoral existence.

We see, therefore, that cataclasmal selection may enforce a character which (1) may be of no benefit in normal life; (2) may carry, associated with it, characters selected by environment before the cataclasm and transmitted because they were possessed by the only surviving organism; while (3) small quantitative differences may have survival value in a cataclasm. We may tentatively con. sider whether some unsolved zoological problems may not be explained by cataclasmal selection. Prof. Poulton ${ }^{3}$ has suggested the interesting case of the whellss of the Red Crag, which are all sinistral. He has considered the probable explanation of this to be that there was a sudden refrigeration, which killed all but one whelk which happened to be sinistral, and that her progeny repopulated the Crag.* Great cold, great heat, and floods are the most widely recognised depopulating ageneies in our past history: it may be permitted, interrogatively rather than assertively, to sketch some possible evolutionary results of the cataclasms such convulsions must have caused.

The mass-wanderings of lemmings, and in a less degree of mice, rats, and squirrels, appear explicable if we assume a mutational madness, the possessors of which were the only survivors of their kind from the glaciation of northern Europe, and their descendants the only rodents to spread themselves over northern Europe when free of ice again. The most inexplicable feature of the wanderings is the

* In 1882 all the Tile-fish off Nantucket were killed, 5000 to 7500 square miles of sea being covered with dead or dying fish, estimated to number "one billion " (query, a thousand million?), fffty being counted in a square rod. This was attributed to the temporary lowering of in a square rod. This was attributed to the temporary lowering of Washington, $p, 612$.

No. 3160 , Vor. 125$]$ 
lemmings throwing themselves into the sea. Darwin's visualisation of the glacial epoch is helpful : "The inhabitants of the more temperate regions would at the same time travel southward, unless they were stopped by barriers, in which case they would perish".4 Therefore the sane lemmings which would not throw themselves into the fjords and rivers perished in the increasing cold. Wiman* describes the state of a modern wandering horde as "a sort of madness"; may we not conclude that this madness was a mutation which had occurred among the lemmings at the Glacial Epoch? Unafraid, the lunatics plunged into the obstructing lake, and because it was mostly frozen got safely across, and continued their lunatic wanderings over insane distances which brought them into gentler climates where they were able to live and produce young lemmings with lunacy inherited from both parents. When the ice had passed these were selected again, because only the lunatics made the return journey; the others stayed south and died as the warmth increased. On this hypothesis, therefore, in the pre-glacial and again in the post-glacial generation every ancestor of the modern northern lemming was possessed with a wandering madness.

It is worth considering whether there may not have been crises in our own ancestry through which no man lived who was not possessed with the appropriate madness, and whether this form of cataclasmal selection may not explain some features in human psychology ; particularly, perhaps, in the behaviour of a crowd. On the other hand, the great drought in the central steppes of Eurasia, which drove our ancestors to migrate with their herds over thousands of miles of wolf-hunted plains, may account for the difference in ability for sustained concerted action between the descendants of the stationary Mediterranean races and those of the migrants. $f$

The "ordeal by fire' is one which must have left its mark in countries where forest-fires or prairiefires are common, and where, therefore, during the ages, from time to time a succession of windchanges will have extended the conflagration until the whole great forest was burned. J. Weigelt ${ }^{5}$ says that one of the chief causes of mortality among larger animals escaping a fire is their being crushed to death by fellow-animals in the stampede Is it possible that the extraordinary lateral spread of the horns of some buffaloes and oxen has enabled their ancestors in such a crisis to survive those of the herd whose horns curved upward or forward?

* Quoted by Weigelt.

+ An observer of lemmings of considerable authority objected, at the meeting of the Linnean Society, that lemmings make no considerable migrations or trsverses of water, but only scatter from infected burrows under the influence of a known bacterial disease which renders them irresistibly thirsty. Another, an authority on rodents, accepted this, and denied the mass-migration of rats or mice. These two authorities are in conflict with the observers quoted by Johannes Weigelt (“Rezente Wirbeltierleichen, 1927, Leipzig, Max Weg, p. 43) : B Högbom observed a dense horde of swimming lemmings 2 to 3 kilometres long near Tromsö, Wiman travelled through such a swimming horde for an hour, and A. Högbom observed a closely packed procession of some sort of field-mouse (all quoted from Paläont. Zeitschr., 1913, Berlin ; Bd. i, p. 147). Waterton was convinced that " rats move from place to place in large bodies" (" Natural History Essays" [1870], London Frederick Warne, p. 241), but he only quotes one witness. Lyddekker (Enc. Brit., 1910-11, " Lemming ") bases on Collett a circumstantial description of mass-migrations of the lemmings lasting one to three years and writes that they are "impelled by the restless or migratory instinct
possessed in " a less developed degree by so many of their congeners".
I am told that in Australia the first sign of a fire in the forest is the escape of the winged thingsbirds and insects. This gives another reason for delicate olfactory organs in insects, equally cogent with sex or food.

In Australia every tree and bush is burned, and nothing remains but hot ashes-through which the seedling eucalypti rise to refill the long swath in the forest. But in Siam and India the old teaktrees stand, and in Honduras the mahogany trees, and Pinchot ${ }^{6}$ says that in the United States, "Trees whose thick bark or abundant seeding gives them peculiar powers of resistance, frequently owe their exclusive possession of vast areas purely to the action of fire". In such resistant trees bees-nests might be unburned even if all the bees were killed by the smoke. Is it conceivable that the use of wax for the cells by social bees, instead of salival cement, has had the survival advantage of protecting the pupæ from the poisonous vapours of the forest-fire which suffocate the adults of the hive?

Is it possible that the high development of the spleen, which can now save the life of a man after moderate poisoning by carbon monoxide, may have been forced upon mammals by forest and prairie fires? It must be remembered that for selective efficiency these disasters need not be frequent if they are terribly mortal.

Dr. G. S. Carter has recently explained ${ }^{7}$ his interesting theory that fishes took to breathing air because of the lack of oxygen in tropical swampwater. I am not aware whether the descendants of any freshwater fish in the Carboniferous epoch were represented as freshwater fish in the Tertiary rocks. A priori it would seem possible that with the enormous extent of stagnant tropical swamps at the time of the coal measures, all their aquatic inhabitants which were not air-breathing were suffocated, and so the sole descendants of carboniferous fresh waters may be the land animals.

I will touch very lightly on the question that interests me very much-the probability, when we find an enormously numerous and powerful group, such as the insects or the birds, predominantly of one design, that their ancestors went through some deadly ordeal in a fairly advanced stage of their history, from which only one (or very few) species survived, so that the orders and families of the group are variations on a highly specialised ancestor the general scheme of whose structure is preserved. Elsewhere I have suggested ${ }^{8}$ that in the case of the insects the ordeal was the violent flooding of the land (cataclysm) in Torridonian times, from which one or possibly two or three species of insects were the only land animals to survive. The Silurian fossil evidence is now considered by entomologists to be negative, but on the other hand they find it difficult to explain the insects of the Carboniferous and Upper Devonian without assuming a long history behind them. ${ }^{9}$

For the birds-is it possible that their ordeal was a sudden development of rapid movement in flesh. eating mammals, which massacred every bird No. 3160, Vox. 125] 
(excluding ostriches, penguins, and so on) except the one species which had learned to perch on a fine twig? I am too ignorant to judge or discuss this question, and am conscious that we have touched above on many questions as to which I am culpably ignorant, and seek and expect correction. My object, in thus inviting personal humiliation, has been to ask each biologist whether, in the groups of which he has knowledge, the recognition of cataclasmal selection may not ex- plain otherwise inexplicable characteristics, as it appears to me to do in the littoral sponges.

${ }^{2}$ Described in Proc. Linn. Soc. for Mar. 6, 1930: "In the Canopy of the Forest ", by Major R. W. G. Hingston.

2 Quart. Jour. Micr. Sci., 67, p. 293; 1923

\& Proc. Linn. Sóc. for Feb. 6, 1930.

- Origin of Species" (First Edition), p. 366

L Loc. cit. p. 40.

"Forests and Forestry", Enc. Brit., 1910-11, p. 658

Proc. Linn. Soc. for April 18, 1929, p. 53.

Prit. Assoc Rep. (Leeds), 1927, p. 60

Tillyard: NatURE, June 12, 1926; Trans. Ent. Soc. Lond., 76, p. $70 ; 1928$.

\section{Obituary.}

\section{Dr. JAMES Waterston.}

$\mathrm{T}^{\mathrm{H}}$ HE death of James Waterston, which occurred on April 28, some weeks after a serious operation, is a severe blow to applied no less than to systematic entomology. For many years past Waterston's entomological interests, though largely concerned with the British Mallophaga (bird-lice) and with the Siphonaptera (fleas), had centred chiefly in the, usually minute, Hymenoptera known comprehensively as Chalcidoidea, many of which are of extreme importance as being in the larval state parasitic in caterpillars destructive to crops, in the pests of stored grain, and in other harmful insects such as tsetse-flies.

Born at Paisley on Feb. 7, 1879, Waterston was educated at George Watson's College and the University of Edinburgh, where he graduated, with honours, in divinity, philosophy and science, and afterwards proceeded to his doctorate in the latter subject. After spending some years in the ministry of the Free Church of Scotland, during which he published many papers on ectoparasites, Waterston resigned his living in the Shetlands, and, in April 1914, joined the staff of the Imperial Bureau of Entomology; his interest in and work upon the Chalcidoidea date from this period. In May 1917, after receiving a temporary commission in the R.A.M.C., Waterston was appointed entomologist to the Malaria Commission, Salonica, being afterwards mentioned in dispatches and demobilised after the Armistice with the rank of captain. On May 20, 1920, he left the service of the Imperial Bureau of Entomology and entered that of the Trustees of the British Museum, in which at the time of his death he occupied the position of assistant keeper (first class) in the Department of Entomology.

A good all-round zoologist, capable botanist, and strenuous and enthusiastic worker at the groups of insects which more especially appealed to him, Waterston was also a prolific writer, and, commencing in the year 1903, published no fewer than one hundred and sixty-four entomological papers. While the majority of these more particularly concern the systematist, the list includes pamphlets on fleas and lice (in the British Museum "Economic" series), and a valuable paper on the bionomics of sand-flies (Phlebotomus), issued in 1922 as one of the results of his field experience in Macedonia. Among the projects abruptly terminated by Waterston's untimely death is a monograph of the British
Mallophaga, for which a portion of the text and many of the illustrations had already been prepared.

Waterston's wide knowledge was ever at the service of those who sought his aid, and few of those who did so and found him at work at his table in South Kensington can fail to have been struck with his marvellous gifts as a dissector of tiny insects. To see him disarticulate, and display on a microscope slide, the mouth-parts or genitalia of a Chalcid, which itself measured but a millimetre or two in length, was a lesson in technique not easily forgotten.

E. E. Austen.

\section{Mr. Hugh S. R. Elliot.}

By the lamentable aeroplane accident which occurred at Hampton in Middlesex on May 6, an able and popular writer on scientific and philosophical subjects has been removed from our midst at the early age of forty-nine years. Mr. Hugh Samuel Roger Elliot was born on April 3, 1881. His father was the Hon. H. F. H. Elliot, son of the third Earl of Minto ; and he himself was a cousin of the present earl. He was educated at Eton and at Trinity College, Cambridge. But his career at Cambridge was cut short through the outbreak of the South African War in 1899, when he obtained a commission in the Coldstream Guards.

On leaving the army in 1902, Mr. Elliot devoted himself largely to scientific and philosophical studies. His first considerable literary undertaking was to edit the two volumes of "The Letters of John Stuart Mill", which appeared in 1910. This piece of work he accomplished with conspicuous care and thoroughness ; and his estimate of Mill's character and achievements in the introduction is remarkably just and discerning. Unfortunately, one can scarcely speak in like terms of the book he published two years later, entitled "Modern Science and the Illusions of Professor Bergson". While, no doubt, he did succeed in exhibiting some of the weaknesses of Bergson's philosophy, he had too little patience with Bergson's mode of thought to appreciate its real significance, and his criticism of it was for the most part superficial and ineffective. He was far more at home in the volume he wrote on "Herbert Spencer ", which was one of a series edited by Basil Williams and published in 1917. In his younger days he had been a fervent admirer of Spencer; and although, after an interval of fifteen years, he had come to see that much of the 'synthetic

No. 3160, Vou. 125] 